hauptsächlich in sandigen Horizonten mit fortgeschrittener diagenetischer Entwicklung auf und dürfte mit großer Wahrscheinlichkeit im Sediment neugebildet worden sein.

Die Untersuchungen werden fortgesetzt.

Mineralogisch-Petrographisches Institut der Universität, Tübingen

W. v. Engelhardi, Germ. Müller und H. Kromer

Eingegangen am 12. Februar 1962

1) BRINDLEY, G.W., u. F. H. GILleRY: Amer. Mineralogist 41 169 (1956). - 2) BRIndefy, G.W.: Chlorite Minerals, in: X-ray identification etc. London 1961. - 3) MúlLER, G.: Neues Jb. Mineral. Mh. 1961, 112. - $\left.{ }^{4}\right)$ BRYDon, J.E., J.S. Clark u. V. OsBORNE: Canad. Min. 6, 595 (1961).—5) MüLLER, G.: In Bearbtg. 6) Weaver, C.E.: Bull. Amer. Assoc. Petrol. Geologists 42, 254 (1958), - 7) Hexing, D.: Diss. Tübingen (in Bearbtg.)

\section{Absorption Spectra of Some Molecular Complexes}

The molecular complexes formed between electron donors of low ionisation potential and acceptors of high electron affinity have their charge transfer absorption bands at relatively longer wave-lengths often well separated from the absorption bands of the components themselves. As the aromatic and aliphatic amines are strong electron donors they should form stable molecular complexes with chloranil, bromanil and iodanil which are known to be good electron acceptors. With this in view the present investigation was undertaken.

The solutions of 0.05 to $0.1 \mathrm{M}$ of the donor and $10^{-2}$ to $10^{-4} \mathrm{M}$ of the acceptor were prepared. The spectral measurements were made within an hour after the preparation of the solutions because on keeping the mixture for some time the solution became hazy due to precipitation. Although the optical density changed with time in some cases, the positions of the absorption bands were reproducible. The peaks of the absorption bands of the complexes (in $\mathrm{m} \mu$ ) are recorded in the Table.

The absorption bands of the chloranil complexes with aniline and $\mathrm{N}$-methylaniline were reported previously in the literature ${ }^{1}$ ) and that they were charge transfer bands was

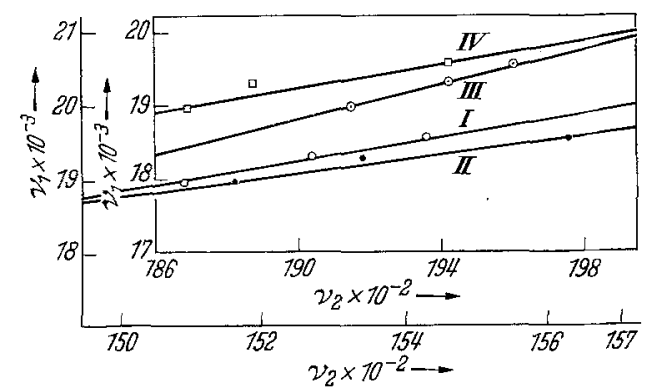

Fig. 1. Frequencies $v_{2}$ of the complexes of the donors (I) Triethylamine, (II) Diphenylamine, (III) Benzylamine and (IV) Aniline with acceptors Chloranil, Bromanil and Iodanil against $v_{1}$ of the complexes of these acceptors with Hexamethyl benzene (solvent carbon tetrachloride)

also established. But the plot of $h v$ against the ionisation potential of the amines for none of the acceptors considered in this investigation is linear suggesting that the stabilization energy of the ion pairs is not constant for all donors. Since the acceptors differ very little among themselves it is plausible that for a given donor the stabilization energy of the ion-pairs with different acceptors should be same. Unfortunately the electron affinities of the acceptor molecules have not been measured. For this reason comparisons have been made of the frequencies where the donor is fixed in a series of complexes with different acceptors.

MCCONELI, HAM and PLATT ${ }^{2}$ ) noticed that the frequency $\nu$ of the charge transfer absorption may be formally expressed by the relation

$$
h \nu=I-E-W
$$

where $I$ is the ionization potential of the donor, $E$, the electron affinity of the acceptor and $W$, the stabilization energy of the charge transfer excited state. If for a series of complexes where the acceptor is varied, the stabilization energies of the ion pairs for a given donor remain same, and $v_{1 y}$ and $v_{2 y}$ be the charge transfer absorption frequencies of the complexes of the
Table. Absorpion bands of molecular complexes of chloranil, bromani and iodanil with some amines. $\lambda$ in $m \mu$

\begin{tabular}{|c|c|c|c|c|}
\hline \multirow{2}{*}{\multicolumn{2}{|c|}{ Donors }} & \multicolumn{3}{|c|}{ Acceptors } \\
\hline & & Chloranil & Bromanil & Iodanil \\
\hline $\begin{array}{l}\text { Triethylamine . } \\
\text { Diethylamine } \\
\text { Diphenylamine } \\
\text { Benzylamine } \\
\text { Aniline } \\
\text { N-methylaniline }\end{array}$ & 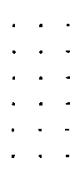 & $\begin{array}{l}655 \\
626 \\
652 \\
515 \\
530 \\
590\end{array}$ & $\begin{array}{l}663 \\
630 \\
660 \\
522 \\
535 \\
600\end{array}$ & $\begin{array}{c}648 \\
665,510 \\
640 \\
510 \\
515 \\
600\end{array}$ \\
\hline
\end{tabular}

given donors (1) and (2) respectively with same series of acceptors $(y)$, then it follows from the equation (1) that

$$
v_{2 y}=x+v_{1 y} ; \quad x=I_{2}-I_{1}-\Delta,
$$

where $I_{1}, I_{2}$ are the ionization potentials of the donors (1) and (2) respectively and $\Delta$ is the difference in stabilization energies of the ion-pairs referred to two donors. In Fig. 1 the $\nu_{2}$ of the complexes of the donors (I) triethylamine, (II) diphenylamine, (III) benzylamine, and (IV) aniline with series of acceptors chloranil, bromanil and iodanil are plotted against, $v_{1}^{3}$ ) of the complexes of these acceptors with hexamethyl benzene (solvent carbon tetrachloride). The slopes of the curves are always nearly equal to unity in agreement with the equation (2). We, therefore, conclude that at least for each of these donors the stabilization energies of the ion pairs with the three acceptors are almost same. For diethylamine and N-methylaniline, however, the linear plot of the equation (2) was not obtained. At present no satisfactory explanation can be put forward for these anomalies. Further, for iodanil complex with diethylamine we observed two peaks in the visible region (Table). The peak at the shorter wave-length may be due to some other type of molecular complex or due to the charge transfer transition to the second vacant orbital of the acceptor molecule.

Department of Chemistry, University Colleges of Science and Technology, 92 Acharya Prafulla Chandra Road, Calcutta-9, India

Saroj Kumar Chakrabarty and Asish Kumar Chandra Eingegangen am 29. Januar 1962

1) Foster, R.: Nature [London] 181, 337 (1958). - 2) McCoNELL, H., J.S. HAM and J.R. PlatT: J. Chem. Physics 21, 66 (1953) 3) Foster, R., D. L. Hammick and P. J. Placito: J. Chem. Soc. [London] 3881 (1956).

\section{Eine Gleichung der Sorptionsisotherme}

Bei der Sorption der Dämpfe von benetzenđen Flüssigkeiten durch kapillarporöse Körper, z.B. Holz, ergeben sich für den Zusammenhang zwischen Stoffeuchtigkeit und relativer Lufteuchtigkeit bei gleichbleibenden Temperaturen charakteristische S-förmige Adsorptions- und Desorptionskurven. Zweifellos handelt es sich bei der Sorption um einen sehr komplexen und verwickelten Vorgang. Chemosorption, Adsorption mit mehrfach molekularen Schichten des Adsorptivs auf der inneren Oberfläche des Sorbens, die über polymolekulare Adsorption in Kapillarkondensation übergeht, sind mit schwankenden Grenzen und sich überlagernd beteiligt. Eine exakte analytische Lösung des Problems wurde wiederholt versucht, gelang aber bisher nicht. Von verschiedener Seite [I. IANGMUIR ${ }^{1}$, H. FREUNDLICH ${ }^{2}$ ), A. G. TJOMKIN und A. SLYGrN ${ }^{3}$ )] wurden für den einfachen Fall der monomolekularen Sorptionstheorie Isothermen abgeleitet, die aber wegen notwendiger vereinfachter Annahmen nur teilweise den Versuchsbefunden gerecht werden. Die mathematische Formulierung der Freundlich-Isotherme lautet:

$$
u=a \cdot \varphi^{n} \text {. }
$$

Hierbei sind $u$ die Feuchtigkeit des Sorbens im Gleichgewichtszustand, $\varphi$ die relative Luftfeuchtigkeit, $a$ und $n$ von der absoluten Temperatur abhängige Konstante.

Die Langmuirsche Theorie wurde von S. Brunauer, P. H. EMmert und E. TELLER ${ }^{4}$ ) erweitert. Die so berechenbaren Kurven stimmen unter der Annahme einer gewissen Molekelschichtdicke, wie P. GörLING ${ }^{5}$ ) zeigte, für $\mathrm{Holz}$ bis zu etwa $\varphi=0,8$ befriedigend mit den Versuchsbefunden überein (Fig. 1). Eine von B. A. Posnow ${ }^{6}$ ) aus den Versuchsergebnissen mehrerer Forscher abgeleitete empirische Gleichung ist nach A. W. Lykow ${ }^{7}$ ) im Bereich $0,3<\varphi<-1,0$ gut 